\title{
Dipeptidyl Peptidase 4
}

National Cancer Institute

\section{Source}

National Cancer Institute. Dipeptidyl Peptidase 4. NCI Thesaurus. Code C91300.

Dipeptidyl peptidase 4 (766 aa, $\sim 88 \mathrm{kDa}$ ) is encoded by the human DPP4 gene. This protein is involved in proteolytic regulation of T cell activation. 